\title{
Oppositions and Appeals at the EPO
}

\author{
Philip M. Webber
}

If you believe that a European patent has been wrongly granted, you can challenge the validity of the patent using the European Patent Office's Opposition procedure. This can result in a limitation of the scope of the patent or even its complete revocation. Oppositions are filed against about 5-6\% of granted European patents.

Although European patent applications are examined by the European Patent Office (EPO) to a high standard before they are granted, such examinations can never be exhaustive. In particular, EPO examiners are unlikely to be aware of novelty- or inventive-step-destroying disclosures such as conference presentations and public displays of the invention before the filing date of the patent application, simply because such disclosures might not have been documented in publicly available written or electronic form. Consequently, it is accepted that some patents do get granted that should not have been if all of the relevant facts had been available to the examiner pre-grant. In an effort to help eliminate the small number of patents in the latter category, the EPO has an Opposition procedure whereby a number of the criteria for patentability can be re-assessed after the patent has been granted. The patent offices of a number of other countries have similar procedures. A summary of the main steps in the EPO's Opposition and Appeal procedures, together with approximate timescales, is given in the TABLE.

\section{Filing the Opposition}

The Opposition must be filed at the EPO within 9 months of the date of grant of the European patent. The opponent must provide full details (and evidence where appropriate) of the reasons for asserting that the patent should not have been granted. The possible grounds for opposing the patent are unpatentable subject matter, lack of novelty and/or inventive step, insufficient disclosure (lack of enablement) and added matter (lack of basis for an amendment). Lack of clarity of the claims is not a ground for Opposition.

After the Opposition has been filed, the patentee is given an opportunity to file a written reply to the issues raised in the Opposition (or Oppositions, for there might be more than one opponent) and then an examiner from the EPO (who is generally the examiner who initially granted the patent) reviews the merits of the arguments put forward by the opponent and patentee. In some cases, they are then invited to submit further written arguments on specific points, but more usually the examiner will then issue a Preliminary Opinion on the issues which have been raised. The examiner will also set a date for a Hearing (also known as 'Oral Proceedings') at which the Opposition will be resolved, and give an indication of the main points to be discussed at that Hearing.

\section{Hearings at the EPO}

Hearings generally take place at the EPO in Munich, Germany, and normally last a few hours. The patentee and opponent (who are usually represented by their patent attorneys) are given the opportunity to present their cases orally before an Opposition Division made up of three EPO examiners and sometimes a legal expert. The proceedings tend to be less formal than court hearings and the exact procedure will depend on the issues in the particular case. In nearly all cases, the decision of the Opposition Division is given orally at the end of the Hearing. There are three possible outcomes which occur with approximately equal frequency: the patent is maintained as granted; its scope is restricted; or it is revoked in its entirety. A written decision that explains the reasons for the decision is usually issued a few months after the Hearing.

\section{Can the decision be appealed?}

The written decision can be appealed by the opponent if the patent has been maintained or by the patentee if the patent has been revoked. If the scope of the patent has been restricted, both patentee and opponent might be entitled to appeal. A Notice of Appeal must be filed within two months of the issuing of the written decision; the Grounds of Appeal must be filed within a further two-month period.

The appeal procedure is generally similar to the Opposition procedure. However, the Appeal Board is made up of different and more experienced examiners than the Opposition Division. The Appeal Board will reassess the arguments and evidence filed by the parties and then either decide to affirm the decision of the Opposition Division or to overturn it. If the Appeal Board overturns the Opposition Division's decision to revoke the patent, the case can be remitted back to the Opposition Division for consideration of any unexamined grounds of opposition. If the Appeal Board revokes the patent, there is no further possibility for appeal.

Philip M. Webber, Ph.D., is at Frank B. Dehn \& Co., Patent and Trademark Attorneys, 179 Queen Victoria Street, London EC4V 4EL, UK. e-mail:philipw@frankbdehn.com

doi:10.1038/nrd1556

\begin{tabular}{|c|c|c|}
\hline \multicolumn{3}{|c|}{ Table | Main steps in the EPO's Opposition and Appeal procedures } \\
\hline Opposition & Process & Appeal \\
\hline $0^{*}$ & European Patent granted & \\
\hline $9^{*}$ & Opposition filed by opponent at EPO & \\
\hline 10 & Opposition copied to patentee by EPO & \\
\hline $16-18$ & Patentee files comments on opposition & \\
\hline $24-30$ & EPO issues Preliminary Opinion and Summons to Hearing & \\
\hline 34 & Hearing at EPO (Oral Decision given at end) & \\
\hline \multirow[t]{8}{*}{36} & Written Decision issues (to maintain, amend or revoke the patent) & $0^{\star}$ \\
\hline & Opponent/patentee files Notice of Appeal & $2^{*}$ \\
\hline & Opponent/patentee files Grounds of Appeal & $4^{\star}$ \\
\hline & Appeal copied to patentee/opponent by EPO & 5 \\
\hline & Patentee/opponent files comments on appeal & $11-13$ \\
\hline & Appeal Board sets date for Hearing & 19-25 \\
\hline & Hearing at EPO (Oral Decision given at end) & 29 \\
\hline & Written Decision issues (to affirm or overturn Opposition Decision) & 33 \\
\hline
\end{tabular}

Approximate timescales for each process are given in months under either the 'Opposition' or 'Appeal' column; entries marked with an asterix denote time periods of fixed duration. EPO, European Patent Office. 